\title{
Isaiah's Vision of Yahweh and Ethical Replication
}

\author{
JACQUELINE N. GREY (UNIVERSITY OF SOUTH AFRICA)
}

\begin{abstract}
This article explores Isaiah's vision of the thrice-holy Yahweh and his message of ethical replication. According to Elaine Scarry, the presence of beauty prompts replication. This will be adapted to consider the role of holiness as a driving factor in Isaiah's message of social justice. First, Isaiah is de-centred in his experience of Yahweh's beauty and terror. Secondly, Isaiah volunteered to embody the message of Yahweh and to call his community to similarly mirror Yahweh in their religious and moral life. By focusing on the use of Isaiah's key terminology of "the Holy One of Israel" in Isaiah 1-39, the expectation of ethical replication among the covenant community is examined. Thirdly, as this key term is also prevalent in chapters 40-66, arguably the expectation for ethical replication was continued by the disciples of Isaiah. This study reinforces holiness as having ethical as well as religious importance in Isaiah's message.
\end{abstract}

KEYWORDS: Isaiah, holiness, beauty, aesthetics, ethics

\section{A. INTRODUCTION}

It is a privilege to contribute to this festschrift in honour of the life and ministry of Professor Wilhelm Wessels. I have known Prof Wessels for many years, particularly through his association and involvement in the Society for Pentecostal Studies. He has been an active participant, presenter, as well as a mentor for many younger scholars. His presence and contribution to global Pentecostalism have been greatly valued. His scholarship, particularly focusing on the prophets of the Hebrew Bible/ Old Testament and ethical challenges, has contributed significantly to the field of biblical studies. His work has raised issues such as abuse of power and challenged both the academy and church towards greater integrity. However, what has always impressed me most about Prof Wessel is that he also lives his message of integrity. Therefore, it is the concept of ethical replication that I wish to explore in this article in his honour.

Isaiah's vision of Yahweh in his call narrative of chapter 6, presents an experience of overwhelming beauty, terror and majesty. One of the defining features of Yahweh in this vision is holiness; a holiness that the prophet realises he does not replicate. Yet, once provision is made and his lips are purified by the

Submitted: 21/08/2018; peer-reviewed: 14/09/2018; accepted: 21/09/2018. Jacqueline N. Grey, "Isaiah's Vision of Yahweh and Ethical Replication," Old Testament Essays 31 no. 3 (2018): 591-612. DOI: https://doi.org/10.17159/2312$\underline{3621 / 2018 / v 31 n 3 a 11 .}$ 
burning coal, Isaiah volunteers to be a spokesperson for Yahweh. The prophet is sent as an embodied sign, or model of mimetic replication. He will be a voice calling his community to similarly mirror the holiness of Yahweh. This study will suggest that the ministry of Isaiah in calling Judah to cultivate their ethical life is significantly prompted by his vision of Yahweh's holiness. That is, there is a connection between Isaiah's experience of Yahweh, his use of the catchphrase of "Holy One of Israel," and his message of ethical replication (particularly in Isaiah 1-39). To explore this connection, I will be adopting the work of Elaine Scarry to explore notions of beauty and aesthetics in Isaiah's call and subsequent ministry. While Scarry explores the role of beauty in the cultivation of contemporary political life, I will be adapting this to explore the role of beauty and holiness in the cultivation of ethical life which, for the community of Judah in the eighth century, of course, had political implications.

First, Scarry suggests that in the presence of beauty the beholder undergoes a kind of de-selfing or enters a state of opiated marginalisation. The vision of Isaiah will be examined in the light of this idea of de-centring - as the prophet is overwhelmed by the holiness and majesty of Yahweh, he realises his own nothingness. However, Scarry also suggests that the presence of beauty prompts replication. This will, secondly, be explored through an analysis of Isaiah's usage of the key terminology "Holy One of Israel." Each usage of this phrase in chapters 1-39 will be examined to analyse the message of the prophet, particularly if and how he seeks the replication of Yahweh's holiness in the social and political life of the Judean community. However, the catch-phrase ("Holy One of Israel") is not unique to First Isaiah but is used consistently throughout the book. Therefore, thirdly, this study will consider the ongoing ethical replication of holiness in the disciples of Isaiah as suggested by the continuation of his message in Second and Third Isaiah and the redactional activity of the book as a whole.

\section{B. ON SEEING BEAUTY}

The turn towards beauty among contemporary philosophers is a turn towards a political vision for postmodern societies. ${ }^{1}$ As part of the Western philosophical tradition, it tends to focus on the social impact of beauty. A significant voice in this field is Elaine Scarry, who sees in beauty an opportunity to heal the wounds of social injustice. Scarry bases this on the Greek philosophical tradition that beauty tends to be symmetrical, proportionate and balanced - which should also be the goal in the social and ethical outworking of society. Beautiful persons and objects are recognized as such because they conform to a notion of symmetry

${ }^{1}$ For further development on this idea, see Mark Canuel, Justice, Dissent and the Sublime (Baltimore, MD: The John Hopkins University Press, 2012). 
whereby constituent parts balance or mirror one another. ${ }^{2}$ Scarry argues that because beauty is characterised by symmetry-which is understood as a replication of similar parts - then beauty prompts the replication of balance and symmetry in society. This provides a basis or model for a just and fair society. A corollary of this symmetry and mirroring that is foundational to beauty is the idea of replication. Scarry asserts, "beauty prompts a copy of itself." "When the beholder sees an object of beauty, he/she wants to replicate or reproduce the experience of beauty - whether that be a photograph of a sunset; the begetting of children from an attractive person; the recording of an idea; a poem capturing a beautiful experience.

However, of particular interest for this reading of Isaiah's encounter of the thrice-holy God is that while Scarry's idea of beauty is replicable, it is not necessarily repeated. That is, according to Scarry, beauty is contextual and only occurs in the particular. ${ }^{4}$ The sunset that prompts photographic replication is a particular occurrence or experience. In that experience of a particular moment, the beholder is de-centred. The beholder realises, for example, that they are not the centre of the universe. However, the experience of pleasure and beauty of the sunset makes this a sublime moment of de-centring. Scarry describes this as a state of "opiated adjacency." The beholder experiences pleasure and sublimity at the same moment that beauty places them on the margins. Because the experience is unique and autobiographical it cannot be repeated but can be replicated. In this sense, it can also become a somewhat shared experience with others. Yet, as Canuel warns, the supposed redemptive power of beauty, as described by Scarry, can become restricted to repetitions of sameness and exclusions of difference. It can lead to empty forms that prioritise symmetry and mirroring at the expense of justice. This will be seen in the discussion of Isaiah's community, who according to the prophet, had empty and shallow forms of religious practice at the expense of social justice.

The study of beauty and aesthetics specifically in the Hebrew Bible/ Old Testament is modest but varied. ${ }^{6}$ This is for a good reason. Philosophical

2 Elaine Scarry, On Beauty and Being Just (Princeton, NJ: Princeton University Press, 1999), 96. Scarry notes the connection between 'beauty' and 'fair' that correlates to 'fairness' and 'fair play.' This is also somewhat reflected in the Old Testament as Luke Ferreter notes, "The word for 'beauty' is $y^{\circ} \mathrm{pi}$, and the adjective yäpeh means 'beautiful' As the terms' frequent association with to'ar, 'form', and mar'eh, in phrases which literally mean 'beautiful in form' or 'beautiful' indicates, they refer primarily to the external form." (Luke Ferretter, "The Power and the Glory: The Aesthetics of the Hebrew Bible' LT 18 no. 2 (June 2004), 124.)

3 Scarry, On Beauty, 4.

4 Scarry, On Beauty, 18

5 Scarry, On Beauty, 119.

6 Various studies on beauty and aesthetics in the Hebrew Bible/ Old Testament include: David Penchansky, 'Beauty, Power, and Attraction: Aesthetics and the Hebrew 
reflection on aesthetics tends to be a later, Greek development, so there are minimal musings on beauty as an abstract concept in the Old Testament. ${ }^{7}$ Yet, as scholars such as David Penchansky highlight, the idea of beauty is evident throughout the writings of ancient Israel; it just looks different and is less systematized than later Hellenistic developments. Penchansky observes that there is no one equivalent word in Hebrew for 'beauty' but a cluster of words. He notes that the terms for 'beauty' most used in the Old Testament generally only refer to people and not to God. Instead, other terms are utilized to refer to the 'beauty' of Yahweh, such as majesty, glory and splendour (Job 40:10). These terms are connected to kingship and therefore suggest obeisance and obedience. ${ }^{8}$ While Penchansky questions if these terms are even 'beauty words' he does respond somewhat affirmatively that are connected to beauty because these characteristics are what draw people to God. ${ }^{9}$ If definitions of beauty include the attraction between the beholder and the object they are drawn towards, then Yahweh as majestic king is a vision of beauty because the beholder is drawnalbeit attracted by terror and the mysterium tremendum ${ }^{10}$-as well as glorious splendour.

The Psalmist also connects the idea of the beauty of Yahweh with holiness. The King James Version of Psalm 29:2 calls worshippers to "worship the Lord in the beauty of holiness." James Martin observes that the term beauty in the KJV is translated elsewhere as "splendour of holiness." 11 Again, this emphasizes that while there is no abstract theorizing about aesthetics in the Old

Bible' in Richard J. Bautch \& Jean-Francois Raçine (eds) Beauty and the Bible: Toward a Hermeneutics of Biblical Aesthetics (Atlanta GA, SBL Press, 2013) 47-66; Loader, James A., 'The Pleasing and the Awesome,' OTE 24/3 (2011): 652-667; Luke Ferretter, 'The Power and the Glory: The Aesthetics of the Hebrew Bible' LT 18 no. 2 (June 2004) 123-138; William A. Dyrness, 'Aesthetics in the Old Testament: Beauty in Context,' JETS 28 no. 4 (December 1985): 421-432.

7 Von Rad suggested that any study of beauty in the Old Testament would distort the material. This is because von Rad considered the concept of beauty presented in the Old Testament as a basic experience common to all people (Gerhard Von Rad, Theology of the Old Testament, Volume 1. Translated by D.M.G. Stalker (New York: Harper and Row, 1962). However, it is suggested in this study that there are concrete expressions of beauty that are arguably compatible with the same ideas presented in abstract Greek ideals, while also agreeing with von Rad that aesthetics and beauty as an abstract concept (as it is understood in the Western philosophical tradition) is not reflected in Old Testament material.

8 Penchansky, David, 'Beauty, Power, and Attraction: Aesthetics and the Hebrew Bible' in Richard J. Bautch \& Jean-Francois Raçine (eds) Beauty and the Bible: Toward a Hermeneutics of Biblical Aesthetics (Atlanta GA, SBL Press, 2013), 47-8.

9 Penchansky, 'Beauty, Power, and Attraction,' 53.

10 Rudolf Otto, The Idea of the Holy (Oxford: OUP, 1982) 15-22

11 James A. Martin, Beauty and Holiness: The Dialogue Between Aesthetics and Religion (Princeton, NJ: Princeton University Press, 1990), 9. 
Testament, beauty is something that is experienced and identified with concrete settings. Hubbard argues that the Biblical view and the Greek view stand in contrast as the latter presents an external, formal ideal while the former considers something beautiful if "it displays the integrity that characterizes creation and that in turn reflects God's own righteousness." 12 Yet, these notions are not as incompatible as Hubbard seems to suggest. Similarly, it will be argued below that the ideas promoted by Scarry are not incompatible with the Old Testament despite Scarry's reliance on Greek and Western philosophical traditions. While ancient Israel may not have philosophized on aesthetics, they did have an awareness of beauty in their particular and concrete experiences, such as in their experiences of God, in their creation of beautiful objects, appreciation of beauty in people (such as Rachel in Gen 29:17), ${ }^{13}$ as well as in their expressive poetry. In those experiences and expressions of beauty they also valued symmetry, proportion and balance. This is seen in realities such as the poetic yet structured order of creation reflected in Genesis 1; the symmetry, balance and harmony of the Temple building (described in 2 Kings 6) - the Temple, also referred to as a "holy and beautiful house" (Isa 64:11) ${ }^{14}$; the poetic delight of the Psalmist in Yahweh's creation (Ps 19) with its use of parallelism and symmetry; and the admiration for the order of creation that is imitated in the poetry of Job. ${ }^{15}$ It is also evident in the experience of Isaiah as he beholds the glory of Yahweh. ${ }^{16}$

\section{ISAIAH'S AUTOBIOGRAPHIC BEHOLDING OF YAHWEH'S BEAUTY}

The vision of Isaiah, as described in his autobiographical account (Isa 6:1-13), is an experience of beauty. The prophet's encounter with Yahweh, particularly described in 6:1-3, is one of balance, wholeness and symmetry. Yahweh's robe 'fills' the temple, just as Yahweh's glory 'fills' the earth; constituting a sense of wholeness and fullness. The gigantic proportions of Yahweh (that are representative of this powerful and transcendent deity) are also expressed in this description; it is only Yahweh's robe that can be contained in the temple. The

12 Robert L. Hubbard, 'The Eyes Have It: Theological Reflections on Human Beauty,' ExAud 13 (1997) 430.

13 Hubbard, 'The Eyes Have It,' 57-72.

14 Ferretter, 'The Power and the Glory,' 126.

15 Martin, Beauty and Holiness, 10.

16 James A. Loader writes, "The divine speech in Job 38ff. shows a deep admiration for the natural order, the profundity of which can only be wondered at in awe. Since only God understands his handiwork, humans can only marvel at it. The structure of the carefully constructed poem mirrors the deeply thought out order of God's creation. The profound harmony manifests the character of the beautiful as that which impresses absolutely - just as every individual work of art produced by God's creative activity" (James A. Loader, 'What do the heavens declare? On the Old Testament motif of God's beauty in creation' HTS Teologiese Studies/Theological Studies 67/3 (2011), Art. \#1098, http://dx.doi.org/10.4102/hts.v67i3.1098, 7) 
proportion and balance of the attendants are conveyed in the seraphim standing at attention above the enthroned, heavenly king. Each of these seraphim has six wings. Their paired wings provide symmetry and balance as they are a replication of similar parts. With two wings they cover their face (top), with two wings they cover their feet (bottom), ${ }^{17}$ and with two wings they fly. They are balanced in their twin calling of one to another; they mirror and echo the same message of Yahweh's holiness and glory. This balance, wholeness and symmetry is not abstract or theorised; it is encountered. This vision of Isaiah expresses a balance, wholeness and symmetry associated with Yahweh, who is considered glorious and beautiful. However, as the response of Isaiah indicates, the beauty of Yahweh is also dangerous.

Isaiah is both impressed and overwhelmed by this vision of the beautiful, ${ }^{18}$ powerful and holy Yahweh. Loader writes, "beauty by definition overwhelms." ${ }^{19}$ Prof Wessels highlights the role of the senses of the prophets (particularly seeing and hearing) in receiving Yahweh's word ${ }^{20}$ In this case, Isaiah not only sees and hears, but he feels, smells, and later tastes the experience of Yahweh in an overwhelming of the senses. His response to this theophanic encounter is one of terror. Rudolf Otto in The Idea of the Holy, describes this experience of Isaiah as "mysterium tremendum." He says it is the "hushed, trembling, and speech-less humility of the creature in the presence of whom or what? In the presence of that which is a Mystery inexpressible and above all creatures." 21 But it is also 'tremendum' - an extraordinary dread or majestic terror. It is a captivating, mystical awe that overpowers the subject and causes them to physically shudder. Those that are powerful are not only feared, but also considered beautiful. ${ }^{22}$ As Ferretter writes, "The impression of power is an essential part of beauty in the Old Testament." 23 In this way, Yahweh is experienced by Isaiah as beautiful, holy, glorious and terrifying.

For scholars such as von Rad, the encounter of Yahweh in a theophany is a key to understanding the beauty of Yahweh. Von Rad writes:

17 It is noted that some scholars understand the term 'feet' as a euphemism for genitals, yet the idea of balance and symmetry is still evident in the poetic use of feet as imagery.

18 As Loader writes, "the essence of beauty is that which impresses." (Loader, 'The Pleasing and the Awesome,' 664)

19 Loader, 'What do the heavens declare?' 5.

20 Wilhelm J. Wessels, 'Prophetic sensing of Yahweh's word', HTS Teologiese Studies/ Theological Studies 71/3 2015, Art. \#2923, 9 pages. http://dx.doi.org/10.41 02/hts. v71i3.2923, 1.

21 Otto, The Idea of the Holy, 13.

22 James A. Loader, 'The Pleasing and the Awesome,' 661-2.

23 Ferretter, 'The Power and the Glory,' 128. 
The descriptions of theophanies are undoubtedly the most central subject of an OT aesthetic, for they reveal more clearly than all else how the special experience of God undergone by Israel became normative for the special features in the experience of beauty. ${ }^{24}$

What is revealed in Isaiah's theophanic experience? How is Yahweh described? Yahweh is holy. Like the Psalmist, Isaiah's experience connects the idea of the beauty of Yahweh with holiness - and as will be discussed below, beauty and holiness also have ethical importance. Yet, what does it mean for Yahweh to be 'holy'? Usually definitions include either moral purity, or a sense of transcendence and separateness, or both. Yet contained within these ideas is a sense of balance, order, harmony and wholeness. Yahweh is holy and exalted, yet Yahweh's glory fills the whole earth (Isa 6:3). It is not just the temple that is filled with Yahweh's glory, but all of creation. It reveals Yahweh's intention to establish justice and righteousness on the earth. The holiness and beauty of Yahweh are intended to be realised. The holiness of Yahweh redeems and transforms all it touches. ${ }^{25}$ However for Isaiah and his community that are selfproclaimed as having "unclean lips" (Isa 6:5), this holiness appears lifedestructive.

Isaiah initially responds to the vision of Yahweh's beauty and holiness with fear. He stammers: "Woe is me! For I am destroyed" (Isa 6:5). Isaiah's encounter with the living God produces an unselfing, or what Otto calls "creature-consciousness." 26 The vision of Yahweh is overwhelming intense; it causes the beholder to respond in a self-deprecating, annihilation of the self. ${ }^{27}$ Of course in the Hebrew tradition, no one can see God and live. ${ }^{28}$ So Isaiah's encounter with the beauty and terror of Yahweh results in a sense of decentring. ${ }^{29}$ A new orientation is established in which Yahweh is the centre of the universe, not the beholder. However, through the unusual provision of a burning

24 von Rad, Theology of the Old Testament, 366-367. A more recent development of this idea is presented convincingly by James A. Loader in which he argues for the "paradoxical presence of the motif of not-seeing in Old Testament theophanies where God himself appears" (James A. Loader, "What do the heavens declare? On the Old Testament motif of God's beauty in creation', HTS Teologiese Studies/ Theological Studies 67/3 ( 2011), Art. \#1098, 8 pages. http://dx.doi.org/10.4102/hts. v67i3.1098, 1).

25 Dyrness, 'Aesthetics in the Old Testament,' 427.

26 Otto, The Idea of the Holy, 10.

27 Otto, The Idea of the Holy, pp.15-22.

28 Roberts notes that this response of sheer terror is also connected to the Exodus text (Ex 33:20) that no one can see God and live. Isaiah 1-39, p.99.

29 For further reflection on the de-centring of Isaiah, see Jacqueline Grey 'Beauty and Holiness in the Calling of Isaiah' in Martin, L.R., (ed) A Future for Holiness: Pentecostal Explorations (Cleveland, TN: CPT Press, 2013) 47-58. 
coal, Isaiah experientially discovered that Yahweh's holiness is not lifedestructive but life-enhancing. ${ }^{30}$

With a new orientation, Isaiah then responds to this experience of Yahweh's beauty and holiness with replication. Overhearing the powerful, holy deity ask who will "go for us?" Isaiah volunteers to represent and replicate the message of Yahweh through his own person: "Here am I. Send me!" (Isa 6:8). As Prof Wessels observes, the experience of the prophet in the council of Yahweh legitimises their authority as a messenger. ${ }^{31}$ So with lips burnt and redeemed by fire, Isaiah will embody the message. Isaiah's experience of the beauty and holiness of Yahweh prompts him to be set apart for prophetic service. His ministry will be replicating Yahweh through his very life and message as he calls for justice and righteousness in his community. Isaiah has been overwhelmed and changed by his encounter with Yahweh, but the people remain blind and deaf. So Isaiah's life will mirror - as a replication of similar parts-his message. He will be rejected, just as the community has rejected Yahweh (Isa 6:9-10). Yet, even after Isaiah's third child-sign is offered to and rejected by the Judean king, the prophet still proclaims: "Here am I, and the children the LORD has given me. We are signs and symbols in Israel from the LORD Almighty, who dwells on Mount Zion" (8:18 NIV). Isaiah and his children are models of mimetic replication. ${ }^{32}$ As evidenced by his conception and name, Isaiah's third child is particularly birthed as a replication of the message (Isa 8:1-4). The prophet and his children reflect the wholeness and symmetry of Yahweh through their message and life as they call for holiness and justice among their community of a "people of unclean lips" (Isa 6:5 NIV). Like Isaiah, Yahweh's holiness is what the Judean community are called to replicate. However, instead, Judah's leaders are "rebellious children" (Isa 1:4). So Isaiah's message is focused on calling these disloyal children to a new orientation of embodying the holiness and justice of Yahweh that he and his children replicate. When will this happen? When the experience of Isaiah-as modelled and testified by him-becomes the experience of the people. ${ }^{33}$

\section{THE "HOLY ONE OF ISRAEL"}

The theme of Yahweh's holiness experienced by the prophet is reflected throughout the message of the book. The entirety of Isaiah's message is an

\footnotetext{
30 John N. Oswalt, The Holy One of Israel: Studies in the Book of Isaiah (Eugene OR, Cascade Books, 2014) 44.

31 Wessels, 'Prophetic sensing of Yahweh's word,' 1.

32 For further discussion on the embodiment of Isaiah's message in the child-signs, see Jacqueline Grey 'SPS Presidential Address: Embodiment and the Prophetic Message in Isaiah's Memoir,' Pneuma 39 (2017), 431-456.

33 Oswalt, The Holy One of Israel, 141.
} 
outworking of this vision and its implications. ${ }^{34}$ It is also outworked specifically in the use of the catch-phrase title the "Holy One of Israel" 35 adopted by Isaiah to refer to Yahweh. We see this used 12 times in chapters 1-39 and at least 25 times in the book as a whole. ${ }^{36}$ It is a phrase to some extent unique to Isaiah. As Oswalt observes, "Since the phrase is rare outside of Isaiah, yet relatively common and widespread within the book, it seems likely that this term provides a significant key to Isaiah's view of God." "T7 This phrase emphasises that Yahweh is not only holy, but also belongs to Israel. God is exalted and separate, but also self-committed to the community of Isaiah (past, present and future). John Goldingay notes "To add "of Israel" is to say something that risks undoing the expression "Holy One"; the title as a whole threatens to deconstruct. It puts the Holy One into a relationship with a non-holy entity, a relationship from which Yahweh apparently now has no exit. It radically compromises the notion of holiness. The separate one becomes the attached one." 38 As Yahweh is committed to his people and wants to manifest his holiness among them, so Isaiah is committed to and embodies the message of Yahweh among his community despite their rejection. Central to that message is the requirement of holiness to be expressed through ethical lifestyles and justice for the whole community.

34 John Goldingay, Isaiah (Grand Rapids, MI: Baker Publishing, 2001) 8. J. J. M. Roberts adds that "if there is any one concept central to the whole book of Isaiah, it is the vision of Yahweh as the Holy One of Israel." (see J. J. M. Roberts 'Isaiah in Old Testament Theology,' in James Luther Mays \& Paul J. Achtemeier (eds) Interpreting the Prophets (Philadelphia MD: Fortress press, 1987) 63).

35 It is used elsewhere in the OT only six time outside of Isaiah. Why does Isaiah use this phrase for Yahweh 'the Holy One of Israel' so prominently? Oswalt suggests: "Perhaps it was that tremendous vision of God in chapter six, whose central emphasis is the holiness of God. One can well understand how the impact of that experience could alter the prophet's expressions about God for all his days." (see Oswalt, The Holy One of Israel, 42).

36 Writing of this catch-phrase 'Holy One of Israel' Roberts notes: "It is one of Isaiah's favorite epithets for God, and if Isaiah did not coin the epithet, it nonetheless reflects the impression his inaugural vision of Yahweh's holiness (Isa 6:1-5) had on the prophet's understanding of God." (J.M.M. Roberts, First Isaiah: A Commentary (Minneapolis, MN: Fortress Press, 2015) 21). Also to note, Isaiah uses the adjective 'holy' (qados) to describe God more frequently than all the other Old Testament writers combined (see J. A. Motyer, The Prophecy of Isaiah, (Downers Grove: InterVarsity Press, 1993) 17-18).

37 Oswalt, The Holy One of Israel, 41-42. This is also reinforced by John Goldingay who writes: "Holy One of Israel: this is the book's distinctive title for God. It was a title that Isaiah especially took up, presumably as a result of the experience that will be described in chapter 6." (John Goldingay, Isaiah (Grand Rapids, MI: Baker Publishing, 2001) 34).

38 Goldingay, Isaiah, 15. 
To explore the connection between the holiness of Yahweh and the call for Isaiah's community to replicate that holiness in the cultivation of their ethical life, the usage of the term "Holy One of Israel" throughout Isaiah 1-39 will be examined. As noted above, this key phrase is used 12 times in chapters 1-39, generally understood as addressing Judah in the eighth century B.C.E. during the period of the international domination of Assyria in the ANE. Isaiah addresses both the internal social situation and external politics of the Judean community, particularly isolating the leaders for judgement. The leadership is condemned by the prophet for unethical practices, social injustice and lack of trust in Yahweh. They are not mirroring the beauty and holiness of Yahweh; instead they are replicating the other idolatrous nations around them.

\section{Isaiah 1:4}
Ah, sinful nation,
people laden with iniquity,
offspring who do evil,
children who deal corruptly,
who have forsaken the LORD,
who have despised the Holy One of Israel,
who are utterly estranged! (NRSV)

The first use of this term "Holy One of Israel" in a canonical reading of the book is within the presentation of a lawsuit against Judah (Isa 1:2-20). ${ }^{39}$ The prophetlawyer states their case: the children of Yahweh (referring to the covenant community) have rejected and spurned the "Holy One of Israel" (Isa 1:4). The charge uttered by the prophet is that the people do not know Yahweh (Isa 1:3). By using the experiential term yada ('know'), the prophet emphasizes that this is not just an intellectual knowledge of someone or something, but a deeply relational knowledge. ${ }^{40}$ By comparison, an unintelligent animal has better sense and knowledge of their owner than what Israel does of their parent. The prophet adopts this familial imagery to describe them as children who "are given to corruption" (Isa 1:4). This points to the institutionalization of $\sin$ in the structure and activity of the community. That is, the children have learnt their corrupt behaviour from their human parents to the extent that it is now cyclically ingrained in their society and life. As Goldingay writes. "Although they belong to Yahweh's family, they are children given to corruption instead of children

39 This is noted by J.J.M. Roberts who writes: "Moreover, the parallels with Deuteronomy 32; Mic 6:1-8; and Psalm 50 support the analysis of Isa 1:2-20 as a single speech. All of these texts involve a lawsuit between God and the people, and all of them call on heaven and earth, or other personified elements of the natural world, to listen to the case." (Roberts, First Isaiah, 18).

40 As Goldingay notes, “...knowing (v. 3) is a matter of recognition and acknowledgment, of will as well as mind; does not know thus has similar implications to rebelled" (Goldingay, Isaiah, 34). 
with the family likeness." ${ }^{41}$ These children have rebelled-refusing their calling of being a unique and holy people (who reflect the holiness of their parent) and instead have sought to become like the nations around them.

What is the 'family likeness' they should be demonstrating? True family resemblance - that is, ethical replication - should be evidenced in true worship, righteousness and justice. Instead, their rejection of Yahweh has left them sick and ailing (Isa 1:5-6). Empty worship is one example of this poison and sickness that permeates their community (Isa 1:12-13). Systemic injustice is another example of their corporate ailment; their hands are lifted in prayer but are covered in blood (Isa 1:15). Their empty worship and rejection of God are expressed in injustice and fraudulent activities. As Prof Wessels writes, "Prophets are synonymous with the promotion of social justice, and the plight of the poor and needy (which included widows and orphans) did not escape the attention of the biblical prophets. Their messages were at times harsh and to the point, making people aware of Yahweh's appeal for loyalty, obedience and justice." 42 As part of Yahweh's appeal for these rebellious children to return back, he offers them a total transformation that is realized only through true repentance. ${ }^{43}$ This redemption requires them to turn from their current unethical practices; they are not reflecting the 'family values' by their current behaviour. Instead they are to "seek justice, aid the oppressed, support the rights of the orphans. Plead the widow's cause" (Isa 1:17). ${ }^{44}$ While based on Torah living, Childs notes that these expectations ".... are not universal ethical teachings, but a highly existential application of the divine will that had long since been revealed to Israel, and now delivered with a fresh poignancy to a corrupt, complacent, and self-righteous population." 45

To return to their calling of ethical replication, cleansing is needed. Just as Isaiah experienced cleansing through the burning coal scorching his lips (Isa 6:7), so his community needs cleansing. The solution is provided in concrete actions: they are to be cleansed and subsequently change their behaviour to mirror their new orientation (Isa 1:16-17). They are to heal the wounds of social injustice. Yet, a giant chasm exists between their current orientation away from Yahweh and the need to be re-orientated towards him. As J.J.M. Roberts writes “if Isaiah's horrible epithets for Israel underscore their alienation from God, the

41 Goldingay, Isaiah, 35.

42 Wilhelm J. Wessels, 'Prophet, Poetry and Ethics: A Study of Jeremiah 5:26-29,' OTE 21/3 (2008), 729.

43 Brevard S. Childs, Isaiah: A Commentary (Louisville, KY: Westminster John Knox Press, 2001) 17.

44 Childs, Isaiah, 20.

45 Childs, Isaiah, 20. 
prophet's epithet for God, "the Holy One of Israel," expands that gulf while pointing to the relationship that should exist between God and his people."46

\section{Isaiah 5:19, 24}

...who say, "Let him make haste,

let him speed his work

that we may see it;

let the plan of the Holy One of Israel hasten to fulfilment,

that we may know it!"

${ }^{24}$ Therefore, as the tongue of fire devours the stubble,

and as dry grass sinks down in the flame,

so their root will become rotten,

and their blossom go up like dust;

for they have rejected the instruction of the LORD of hosts, and have despised the word of the Holy One of Israel. (NRSV)

The next text is a condemnation of the Judean leadership for failing to mirror the holiness of Yahweh in their society, particularly during the context of the SyroEphramite Crisis. The two uses of the key term "Holy One of Israel" in Isaiah 5 are part of the 'woe' judgements (Isa 5:8-30) on the leaders of Judah following the 'Song of the Vineyard' (Isa 5:1-7). Their sins, as summarised by Oswalt, include "greed (vv. 8-10), self-indulgence (vv. 11-17), cynicism (vv. 18-19), moral perversion (v. 20, 21), and social injustice (vv. 22-24)."47 The usage of the key term emphasises the judgement against the arrogance and self-sufficiency of the leaders who make political alliances like the other nations regardless of the sufficiency of Yahweh. The term "Holy One of Israel" is placed on the lips of the scoffers who "were expressing themselves by sardonic use of Isaiah's own language" 48 to urge Yahweh to hasten his plans and agenda. ${ }^{49}$ The leaders have rejected both Yahweh and his embodied spokesperson, Isaiah. Their dismissal of Yahweh is echoed in their disdain for the prophet. They taunt and mock both him and his message. Child observes that "They have no awe, but dare God "to do his thing." Whatever God does is judged by them to be irrelevant in their world." "50 Their vision of Yahweh is inadequate - these scoffers imagine Yahweh as feeble and impotent. Instead by quoting back to them this catch-phrase, Isaiah underpins his own vision of the holiness of Yahweh. When will they have a proper vision of Yahweh? As noted above, it can only be when the experience of Isaiah becomes the experience of the people.

46 Roberts, First Isaiah, 21.

47 John N. Oswalt, Isaiah, NIVAC, (Grand Rapids, MI: Zondervan, 2003) 113.

48 Joseph Blenkinsopp, Isaiah 1-39 (New Haven; London: Yale University Press, 2008) 214.

49 Roberts, First Isaiah, 82.

50 Childs, Isaiah, 47. 
The prophet continues in Isaiah 5:24 to describe the judgement that will come upon the people because they have rejected the "Holy One of Israel." How have they rejected him? From verse 22, they are self-absorbed hedonists who are corrupt and unjust (verse 23: "who acquit the guilty for a bribe, but deny justice to the innocent"). So, there is a direct connection between the people rejecting the holiness of God and their subsequent unethical behaviour and attitudes in their everyday life. They are only interested in their own personal gratification rather than justice. ${ }^{51}$ They refuse their true family resemblance (or ethical replication) and thereby refuse to respect their covenant brothers and sisters in need.

\section{Isaiah 10:20}

On that day the remnant of Israel and the survivors of the house of Jacob will no more lean on the one who struck them, but will lean on the LORD, the Holy One of Israel, in truth. (NRSV)

The pericope of Isaiah 10:20-23 presents an eschatological vision of the future. ${ }^{52}$ It envisions Isaiah's community turning towards rest and reliance on Yahweh, as modelled by the prophet and his child-sign Shear-Jashub ("a remnant will return"). ${ }^{53}$ It presents a message of hope and restoration following Yahweh's judgement performed by Assyria. It provides hope for the faithful remnant that demonstrate trust in Yahweh. There are two important connections to the term "Holy One of Israel." First, it reinforces the message of justice. Yahweh does that which is right, therefore so should the people hearing Isaiah's message. Yahweh demonstrates his commitment to justice in this vision, albeit by imposing covenant judgement on Judah. By repeated rejection of Yahweh, Judah in turn will be rejected. Punishment and exile were not an empty threat, yet neither was it the last word. A remnant would return, according to Isaiah's vision. This remnant would be marked by faithfulness and trust in the "Holy One of Israel."

Second, this vision of the faithful remnant relying on the "Holy One of Israel" connects with the idea of ethical replication because truly trusting in Yahweh results in a just and righteous society. To not trust Yahweh requires investments in military armaments and relying on military alliances. Where would the funding come for such military expansion? As Isaiah 10:1-4 suggests, the wealth accumulation of the Judean leaders came from the unjust decisions and behaviour of leaders who were robbing from the fatherless and preying on widows. As Prof Wessels notes, "The prophets in particular condemned the social exploitation of those who had few or no rights and fell victim to a system

\footnotetext{
51 Roberts, First Isaiah, 82.

52 Childs, Isaiah, 93.

53 Childs, Isaiah, 94-5.
} 
that was supposed to be to their benefit." 54 Denying justice to the marginalised of the community did not mirror Yahweh's holiness, order and beauty. Instead, quiet trust means turning from their current authoritarian 'taking' at the expense of others. ${ }^{55}$ True trust results in justice, which is an ethical replication of Yahweh's holiness.

\section{Isaiah 12:6}

Shout aloud and sing for joy, O royal Zion, for great in your midst is the Holy One of Israel (NRSV)

The key term "Holy One of Israel" is next contained in the book of Isaiah in an eschatological hymn of praise. It points to the future experience of Isaiah's community being that which Isaiah has already experienced at his call (Isa 6): Yahweh made known to them in greatness and presence. The "Holy One of Israel" is among them-being encountered by them. In this vision, the presence of Yahweh among them is cause for joy and celebration. It is in stark contrast to the first use of this key term in Isa 1:4 in which they were portrayed as rebellious children. Now, they are like the seraphim of Is 6:3, calling one to another in the poetic parallels of proclamation and exaltation. Now, they are like the prophet in Isaiah 6:8 who volunteered to be sent as a spokesperson of Yahweh. The people voluntarily proclaim Yahweh's greatness to the nations. It is a fitting conclusion to the section of chapters 1-12. It opened with juvenile rebellion against the "Holy One of Israel" and closes with a vision "in that day" of voluntary proclamation of Yahweh's greatness.

\section{Isaiah 17:7}

On that day people will regard their Maker, and their eyes will look to the Holy One of Israel; (NRSV)

The next section of Isaiah that utilises the key term "Holy One of Israel" is again an eschatological vision in which idolatry is rejected. There is an emphasis on looking and seeing; the people will "in that day" see as the prophet has already been seeing since his vision of the holiness of Yahweh (Isa 6). This text (Isa 17:1-11) provides hope emerging from judgement for the faithful. Rather than rely on idols or one's own resources (Isa 17:8), the people will "turn their eyes to" the "Holy One of Israel" (Isa 17:7). They will "look to" their Creator rather than the altars they created. Roberts notes the similarities to Isaiah 10:20 in which Israel no longer would rely on human alliances but on Yahweh. However here the criticism is directed towards different false objects of their reliance; it is

\footnotetext{
54 Wessels, 'Prophet, Poetry and Ethics,' 738.

55 This behaviour is connected to 1 Samuel 8 in the broader reading of the Deuteronomistic History, in which the people are warned that the king they demand will 'take' from them-like the other ANE despots.
} 
against the "accoutrements of worship at the local high places." 56 These practices that are criticised no doubt had implications for their worship and ethical life. The emphasis on eyes (looking) and idols reinforces their previous blindness in Isaiah 6:9-10 where they were told to "keep listening, but do not comprehend; keep looking, but do not understand" (NRSV) as their eyes were closed. They worshipped blind idols and became blind themselves. However, in this future vision of Isaiah when the people truly see the glory and holiness of Yahweh as the prophet has seen, they will be responsible to change their lifestyle to reflect, as the created image of Yahweh, the holiness of their Creator in their daily worship and ethical life.

\section{Isaiah 29:19}

The meek shall obtain fresh joy in the LORD, and the neediest people shall exult in the Holy One of Israel. (NRSV)

Similarly, Isaiah 29:17-21 provides a vision of reversal where Isaiah's community will be behaving correctly and ethically because they finally see "the Holy One of Israel." This text is part of a larger section of Isaiah 28-33 that addresses the military expansionism of Hezekiah in preparation for conflict with Assyria. The risky political policy of the Judean leadership was to align with other nations (particularly Egypt) with a similar agenda of independence from Assyria. Isaiah accuses the leaders of scheming and forming elaborate plans in the dark (Isa 29:15-16). ${ }^{57}$ However the prophet announces that "in a little while" (Isa 29:17) Yahweh will intervene. Then, the eyes of the blind will be opened as the "humble" and "needy" rejoice in "the Holy One of Israel" (Isa 29:19). That is, "in that day" Yahweh will intercede for the rights of the poor and marginalised-just as the leadership of Judah should have been doing if they truly understood the holiness of Yahweh. The corruption of the leadership is detailed (Isa 29: 20-21): the "ruthless," "the scoffer," and "those who wait for evil" will be justly judged. "Then" as Childs writes, "in contrast to the deafness and blindness of the old age, the deaf will hear and the blind see. The humble, who are oppressed by the ruthless, will experience joy in a recreated world of peace and justice (32:16ff.)." 58

This intervention will bring joy not only to those deprived of justice but also to creation (Isa 29:17). This text makes clear the message of Isaiah; their political success or failure was not due to their own resources, nor their human alliances, nor their idols, but was found in "the Holy One of Israel"- and the indicator of their true faith in Yahweh was in the moral condition of the Judean society. ${ }^{59}$ As Roberts asserts, "Israel's problem was not religious ignorance in

\footnotetext{
56 Roberts, First Isaiah, 243.

57 Blenkinsopp, Isaiah 1-39, 408.

58 Childs, Isaiah, 219-220.

59 Blenkinsopp, Isaiah 1-39, 106.
} 
the sense that they failed to acknowledge God with the confession of their lipsthey honoured God with their lips (Isa 29:13) — their problem was the failure to acknowledge God by the obedience of their lives." 60

\section{Isaiah 30:11,12,15}

...leave the way, turn aside from the path, let us hear no more about the Holy One of Israel."

${ }^{12}$ Therefore thus says the Holy One of Israel:

Because you reject this word, and put your trust in oppression and deceit, and rely on them;

${ }^{15}$ For thus said the Lord GoD, the Holy One of Israel:

In returning and rest you shall be saved; in quietness and in trust shall be your strength.

But you refused $\mathbf{~}^{\mathbf{1 6}}$ and said, "No! We will flee upon horses"therefore you shall flee! and, "We will ride upon swift steeds"therefore your pursuers shall be swift! (NRSV)

The rapid increase in the usage of the key term "Holy One of Israel" in this section (Is 30:8-17) may reflect a continued rejection of the message of the prophet $^{61}$ and therefore the desperate appeal to his own vision as validation of the veracity of his message. The Judean leadership that reject and oppose Isaiah are decried as "a rebellious people, faithless children, children who will not hear the instruction of the LORD" (Isa 30:9 NRSV). The prophet quotes his opposition in which they demand that he "prophesy illusions" rather than confront them with Yahweh's perspective on their political and social manipulations (Isa 30:11). The political elite wanted Yahweh removed from their political programme. They ordered their visionaries to stop seeing reliable visions, in what Roberts suggests might be "an ironic echo" of Isaiah 6:9-10. Their own plan involved political alliance with Egypt and military mobilization (Isa 30:16 ; 15-17) in preparation for conflict with Assyria. ${ }^{62}$ Judah's leaders sought to mirror the militarization of the other nations rather than mirror the holiness of Yahweh.

By trusting in "oppression" and "deceit" (Isa 30:12) the leaders were arrogantly depending on their self-constructed socially oppressive materialism.

60 Roberts, First Isaiah, 20-1.

61 As reinforced by Isaiah's instruction to write down the message reflected in this text: "Go now, write it on a tablet for them, inscribe it on a scroll, that for the days to come it may be an everlasting witness" (Is 30:8).

62 Roberts, First Isaiah, 390. 
Their solution would increase the economic hardship on the community, felt most by the poor and vulnerable through a situation of increased taxation, forced labour and confiscation of property. ${ }^{63}$ The prophet then reinforces the rejected message from the "Holy One of Israel:" he says, "In returning and rest you shall be saved; in quietness and in trust shall be your strength" (Isa 30:15 NRSV). As Brueggemann writes, "Israel will be saved and strong when it lives in trust, that is, in returning, rest, and quietness. The four terms bespeak attentive adherence to Yahweh. The terms are all rough synonyms for Isaiah's notion of faith, utter reliance upon and complete devotion to Yahweh."64 This text perhaps invokes the image of the prophet's son, Shear-Jashub, earlier pictured in Isaiah 7:1-9 standing silently as his father delivered to Ahaz a comparable message of quiet trust in Yahweh rather than panicked reaction to a situation of political turmoil. ${ }^{65}$ Active obedience to Yahweh would result in not only rest and salvation politically, but also socially. To not trust in the accumulation of military resources but instead rely on Yahweh's resources would relieve the national economic burden shouldered by the poor and marginalised. If instead, the Judean leadership had embraced the message of Isaiah and mirrored the holiness of Yahweh - being separated from the other nations - then it would arguably result in justice for the whole community. However, their continued rejection of this message would result in judgement; they will be destroyed by the military resources ("horses") in which they trust (Isa 30:16-17).

\title{
8. Isaiah 31:1
}

\author{
Alas for those who go down to Egypt for help \\ and who rely on horses, \\ who trust in chariots because they are many \\ and in horsemen because they are very strong, \\ but do not look to the Holy One of Israel \\ or consult the Lord! (NRSV)
}

The next text continues the series of 'woe' oracles ("alas" in the NRSV) in Isaiah 2833 condemning generally the military expansionism of Hezekiah and particularly their reliance on Egypt. Once more, the issue at stake is theological and not just political. Turning to Egypt for help and hope is a rejection of Yahweh. As Childs asserts "Israel's leaders trust in chariots and horsemen and feel that events in the real world do not relate to religious faith." ${ }^{66}$ For Isaiah, this perspective is faulty. After all, horses and humans are simply flesh - they are material, unlike Yahweh the Creator who is spirit (Isa 31:3). ${ }^{67}$ Isaiah condemns the leaders for not seeking the wisdom and guidance of

63 Roberts, First Isaiah, 389-90.

64 Walter Brueggemann, Isaiah 1-39 (Louisville, KY: Westminster/John Knox Press, 1998) 244.

65 For further discussion on the image of this sign-child see Grey 'SPS Presidential Address,' 431-456.

66 Childs, Isaiah, 231.

67 Childs, Isaiah, 232. 
Yahweh before forming their alliance (Isa 30:2). Throughout this section of Isaiah 2833, the prophet is calling them to mirror Yahweh's holiness; to be set apart from the other nations and not participate in the political intrigues and military mobilization that burdened the poor and resulted in injustice. The rejection of Yahweh's quietist policy had ethical implications. Instead, if they truly reflected the holiness of Yahweh in their politics then social justice would be restored.

\section{Isaiah 37:23}

Whom have you mocked and reviled?

Against whom have you raised your voice

and haughtily lifted your eyes?

Against the Holy One of Israel! (NRSV)

The anticipated conflict with Assyria did indeed erupt, resulting in the siege of Jerusalem. As the narrative of Isaiah 36-37 describes, Sennacherib's representative mocks Yahweh as impotent, unable to save them (Isa 36:13-20). While this overall text has a complicated history, ${ }^{68}$ the narrative of Isaiah 37 describes Yahweh responding (through the prophet) to Hezekiah's prayer for deliverance (Isa 37:16-20). The poetic oracle delivered by Isaiah condemned the blasphemous arrogance of Assyria. It is on this basis of faith in Yahweh, exemplified by Hezekiah's prayer, that Zion is symbolised as returning the taunts of the King of Assyria (Isa 37:22). Portrayed as a confident young woman, Zion tosses her head at Sennacherib's false pride and arrogance. She is confident because it is Yahweh that has been "mocked" and therefore Yahweh will respond to crush Sennacherib's blasphemous speech. As Roberts suggests, “Zion's direct questions to the Assyrian king contain an element of astonishment that anyone could be so reckless and foolish as to challenge the power of Yahweh." 69 Sennacherib unwisely has mocked the "Holy One of Israel." The charge against Sennacherib is that he does not acknowledge Yahweh and therefore will be revealed as a charlatan for pretending self-made supremacy (Isa 37:23-29).

Yet while this poetic message speaks of Sennacherib, the actual hearer in the narrative was Hezekiah. The message, as noted, has a theological focus: Yahweh is the true ruler of the world. Just as the seraphim announced that the whole earth is filled with the glory of Yahweh (Isa 6:3), so all creation (including arrogant Assyrian kings) was to be accountable to the "Holy One of Israel." The judgement against Sennacherib is in response to the prayer and faith of Hezekiah. In a time of crisis Hezekiah went to the Temple and-in a kind of replication of the cry of the seraphim-he prayed: "O LORD of hosts, God of Israel, who are enthroned above the cherubim, you are God, you alone, of all the kingdoms of the earth; you have made heaven and earth" (Isa 37:16). The experience of Isaiah

68 For discussion on the redactional history of Isaiah 36-37, see Childs, Isaiah, 259287.

69 Roberts, First Isaiah,469. 
is reflected in this prayer of Hezekiah: the greatness of the Creator, the fullness of Yahweh's presence, his transcendence and holiness. True trust in Yahweh is life-enhancing, resulting in salvation and deliverance. Isaiah experienced this in his call to ministry (Isa 6) and now Hezekiah will experience this in Yahweh's deliverance of Jerusalem and social restoration. Yahweh's holiness is emphasised in the closing of Hezekiah's prayer as he implores "So now, O LORD our God, save us from his hand, so that all the kingdoms of the earth may know that you alone are the LORD" (37:20 NRSV). The vision of Isaiah of Yahweh's holiness and provision - as modelled and testified by him - has now become the experience of Hezekiah and, by extension, the people of Judah.

In summary, the use of the key phrase "the Holy One of Israel" emphasises the call to the Judean community to mirror the holiness of Yahweh. This should be reflected in their political interactions by a demonstration of trust in Yahweh. Rather than trust in idols or their own plans, the prophet calls them to reliance and devotion in their Creator. True trust results in a peaceable community where justice can thrive, rather than the corrupt appropriation of material resources from the poor to fund their self-centred lifestyles and militarisation campaign. The concern for social justice voiced by Isaiah was a call for the community to accurately reflect the holiness of Yahweh in their everyday lives. This term "the Holy One of Israel" will continue to be of great importance for the future Judean community.

\section{E. ISAIAH'S DISCIPLES}

The use of this key term "Holy One of Israel" is not limited to the experience of Isaiah of Jerusalem. It continues as an important phrase throughout the rest of the book. ${ }^{70}$ This suggests that the experience and revelatory knowledge of Isaiah continued to be replicated by his disciples who ministered during the time of exile on Babylon (Isa 40-55) and the re-establishing of the community in Palestine (Isa 56-55). Even within a canonical study of Isaiah it is almost impossible to not acknowledge the contribution of his disciples to the development of the book. Isaiah's voice is not the only human voice heard in this work. There is also the hand of the disciple or disciples of Isaiah. They gathered, preserved and collated the words of the prophet. Of course the exact nature and volume of their contribution is conjecture. However most certainly they provided the structure and order of the book. ${ }^{71}$ In this sense, they also model mimetic replication. They created a copy of the vision of Isaiah so its replication can be perpetuated.

In addition, if we take the theory that chapters 40-55 and 56-66 were written by subsequent disciples of Isaiah, then this emphasises further the idea of ethical replication. The disciples clearly immersed themselves in the words

$70 \quad 41: 14,16,20 ; 43: 3,14 ; 45: 11 ; 47: 4 ; 48: 17 ; 49: 7 ; 54: 5 ; 55: 5 ; 60: 9,14$.

71 Goldingay, Isaiah, 3. 
and experience of Isaiah. They absorbed his vision to the point that they also owned it. As the presence of beauty prompts replication, the disciples adopted and adapted Isaiah's signature phrase. It became their own phrase. While Isaiah's vision of Yahweh was not repeated, it was replicated by them; so much so they could look to Yahweh as the "the Holy One of Israel." They also called for justice, trust in Yahweh and a rejection of idolatry.

While it is beyond the scope of this study to examine each usage of "the Holy One of Israel" in Isaiah 40-56 in detail, some observations are in order. First, the connection between the use of the catch-phrase of "Holy One of Israel" and the message of ethical replication continues in Isaiah 40-56. The phrase is employed by Isaiah's disciples to perpetuate the message of the calling of Israel to mirror the holiness of Yahweh, ${ }^{72}$ and to offer hope for the faithful that Yahweh will intervene to establish true justice. ${ }^{73}$ The message is consistent throughout the entire text. Of course, we will never uncover the redactional layers to determine how much and which parts were the original words of Isaiah and those of his disciples. Perhaps that is the point; perhaps the disciples were so faithful to Isaiah's original experience of "Holy One of Israel" that their contribution is at times difficult to determine.

Secondly, the continued use of this key phrase by Isaiah's disciples highlights the replication of Yahweh's relationality. Throughout Isaiah 1-39 the term "Holy One of Israel" is used to remind the people of Yahweh's commitment to them. This is observed particularly in the use of the term in Isaiah 1:4 where the prophet decries the Judean community as "rebellious children." Rather than rebel, Yahweh calls them to a relationship of trust. They can trust him because he has attached himself to them: He is their Yahweh. This idea of relational attachment then is replicated by Isaiah in his mentoring of his children and disciples. Rickie D. Moore writes: "Raising up the next generation is one of the most crucial and comprehensive themes in the book of Isaiah, but this has not been recognized in previous Isaiah scholarship." children in the book that have a pivotal role in the message of the prophet. Isaiah's hope is in his children, future children and in his disciples. In his vision of the thrice-holy God, the prophet is forewarned of the rejection by the current generation but that the hope is in the future 'holy seed' (Is 6.8-13). Similarly, Isaiah identified himself with his children and disciples. Moore notes, "Isaiah knows the children are signs, he knows they are significant, and he knows his prophetic call is to be their mentor in the light of this revelation."

$72 \quad 43: 3,14 ; 45: 11 ; 48: 17 ; 54: 5 ; 55: 5$.

$73 \quad 41: 14,16,20 ; 47: 4 ; 49: 7 ; 60: 9,14$.

74 Rickie D. Moore, 'The Prophet as Mentor: A Crucial Facet of the Biblical Representation of Moses, Elijah and Isaiah, Journal of Pentecostal Theology, 13/2 (2007): 165.

75 Moore, 'The Prophet as Mentor,'169. 
alone: the "here I am" of his call becomes "here I am and the children." He will bind up his testimony among his disciples (Isa 8:16-18). His message will continue to be replicated by the disciples. The canonical form of the book is a witness to this end.

\section{F. CONCLUSION}

There is a sense for many readers of Scripture that the message of Isaiah was not only important for past communities but for present communities as well. If part of Isaiah's message was one of ethical replication, then there should be consideration of how present communities can also mirror the holiness and beauty of Yahweh in their social arrangements. Therefore, I would like to conclude with the insightful words offered by Prof Wessels regarding the applicability of the prophets to all contemporary social and political locations, including Africa: "The appeal made by the prophets to care for the needs of the poor and the orphaned, to protect their rights and to ensure that their cases are judged fairly, is therefore just as applicable to us as it was to Judean society. It is a call to adhere to the practical need for order in societies, and the practical establishment of that order. A sound legal system is therefore the responsibility of the leaders and the educated for the good of all."76

\section{BIBLIOGRAPHY}

Blenkinsopp, Joseph. Isaiah 1-39. New Haven; London: Yale University Press, 2008. Brueggemann, Walter. Isaiah 1-39. Louisville, KY: Westminster/John Knox Press, 1998.

Canuel, Mark. Justice, Dissent and the Sublime. Baltimore, MD: The Johns Hopkins University Press, 2012.

Childs, Brevard S., Isaiah: A Commentary. Louisville, KY: Westminster John Knox Press, 2001).

Dyrness, William A. "Aesthetics in the Old Testament: Beauty in Context." Journal of the Evangelical Theological Society 28 no. 4 (1985): 421-432.

Ferretter, Luke. "The Power and the Glory: The Aesthetics of the Hebrew Bible" Literature and Theology 18 no. 2 (June 2004) 123-138. https://doi.org/10.1093/ litthe/18.2.123

Goldingay, John, Isaiah. Grand Rapids, MI: Baker Publishing, 2001.

Grey, Jacqueline, 'SPS Presidential Address: Embodiment and the Prophetic Message in Isaiah's Memoir', Pneuma, 39 (2017): 431-456. https://doi.org/10.1163/ $\underline{15700747-03904018}$

Grey, Jacqueline. "Beauty and Holiness in the Calling of Isaiah." Pages 47-58 in $A$ Future for Holiness: Pentecostal Explorations. Edited by L.R. Martin. Cleveland, TN: CPT Press, 2013.

Loader, James A. 'The Pleasing and the Awesome,' Old Testament Essays 24 no. 3 (2011): 652-667.

76 Wessels, 'Prophet, Poetry and Ethics,' 742. 
Martin, James A., Beauty and Holiness: The Dialogue Between Aesthetics and Religion. Princeton, NJ: Princeton University Press, 1990. https://doi.org/10.1515/ 9781400860593

Moore, Rickie D., "The Prophet as Mentor: A Crucial Facet of the Biblical Representation of Moses, Elijah and Isaiah.” Journal of Pentecostal Theology, 13 no. 2 (2007): 155-172. https://doi.org/10.1177/0966736907076334

Motyer, J. A. The Prophecy of Isaiah. Downer's Grove: InterVarsity Press, 1993.

Oswalt, John N. The Holy One of Israel: Studies in the Book of Isaiah. Eugene, OR: Cascade Books, 2014.

Oswalt, John N. Isaiah, NIVAC. Grand Rapids, MI: Zondervan, 2003.

Otto, Rudolf. The Idea of the Holy. Oxford: OUP, 1982.

Penchansky, David. "Beauty, Power, and Attraction: Aesthetics and the Hebrew Bible." Pages 47-65 in Beauty and the Bible: Toward a Hermeneutics of Biblical Aesthetics. Edited by Richard J. Bautch and Jean-Francois Raçine.Atlanta, GA: SBL Press, 2013.

Roberts, J.M.M., First Isaiah: A Commentary. Minneapolis, MN: Fortress Press, 2015.

Roberts, J. J. M. "Isaiah in Old Testament Theology." Pages 62-74 in Interpreting the Prophets. Edited by James Luther Mays and Paul J. Achtemeier.Philadelphia, MD: Fortress Press, 1987.

Scarry, Elaine, On Beauty and Being Just. Princeton, NJ: Princeton University Press, 1999.

Schreiner, Thomas R. The King in His Beauty: A Biblical theology of the Old and New Testaments. Grand Rapids, MI: Baker Academic 2013.

von Rad, Gerhard. Theology of the Old Testament, Volume 1. Translated by D.M.G. Stalker. New York: Harper \& Row, 1962.

Wessels, Wilhelm J. "Prophetic sensing of Yahweh's word." HTS Teologiese Studies/ Theological Studies 71 no. 3 (2015), Art. \#2923, 9 pages. http:// dx.doi.org/10.4102/hts. v71i3.2923

Wessels, Wilhelm J., "Prophet, Poetry and Ethics: A Study of Jeremiah 5:26-29," Old Testament Essays 21 no. 3 (2008): 729-744

Dr Jacqueline Grey, Research Fellow at University of South Africa and Associate Professor of Biblical Studies at the Alphacrucis College, Australia. Email: jacqui.grey@ac.edu.au. ORCID ID: https://orcid.org/0000-0002-3253$\underline{6315}$. 